\title{
Effect of Plant Mineral Nutrition on Tomato Plant Infected with Meloidogyne Incognita Under Greenhouse Conditions
}

\author{
El-Sherif, A.G. *; Gad, S. B. ${ }^{*}$ and Saadoon, S. M. ** \\ *Nematology Res. Unit, Agric. Zoology Dept., Fac. of Agric., Mansoura Univ., Egypt \\ ** Ministry of High Education- Iraq \\ Corresponding author: elsherifmohammed@yahoo.com
}

\begin{abstract}
Tomato (Solanum lycopersicum L.) is one of the most important vegetable plants in the world.Root-knot nematodes (Meloidogyne incognita) causing problems in all growing tomato areas in Egypt. The use of such mineral nutrients is the most environmentally successful method for limiting root-knot nematode damage. In this study seven plant mineral nutrients i.e. calcium sulphate, zinc sulphate, magnesium sulphate, iron sulphate, potassium sulphate N.P.K(20:20:20) and urea (5g/pot each) separately were evaluated comparing with oxamyl on root-knot nematode (1000 second stage juveniles/ pot each) infecting tomato plant cv. Castle Rock under greenhouse conditions $\left(19 \pm 3^{\circ} \mathrm{C}\right)$. Calcium sulphate showed the maximum values in improving total plant fresh weight $(65.0 \%)$, plant length $(80.2 \%)$, shoot dry weight $(97.2 \%)$ and number of leaves per plant $(24.2 \%)$, with the highest reduction percentage in nematode population density that averaged $92.3 \%$, followed by that of urea application (85.5\%), respectively. Rates of nematode build-up under the stress of seven mineral nutrients and oxamyl were adversely affected. Such rates ranged between 0.1 to 1.8 vs 4.2 for nematode alone. Namely, calcium sulphate treatment had reasonable lower value of reproduction, (0.3) while, that of zinc sulphate had the highest one (1.8), whereas oxamyl recorded a lowest rate (0.1), respectively. Oxamyl as a systemic nematicide ranked second to calcium sulphate in suppressing nematode population density (88.7\%), and ranked first in diminishing galls and eggmasses numbers with values of 88.2 and $100.0 \%$, respectively.
\end{abstract}

Keywords: Mineral nutrition, cultural control, Meloidogyne incognita, tomato plants.

\section{Introduction}

Root-knot nematodes (Meloidogyne spp.) are very common in all soil types with a wide host range and cause problems in many annual and perennial crops. Tomatoes are among the most seriously affected with these parasitic nematodes causing problems in all growing areas. Root-knot nematode problems increase and control becomes more difficult when tomatoes or other susceptible crops are grown without pre-protection tactic. The use of cultural control method is the most environmentally sustainable and potentially successful method for limiting root-knot nematode damage. Many different types of plant nutrients and fertilizers have been 
applied to soil to suppress populations of such plant parasitic nematode and improve crop yield and plant health (Shalaby, 2012). Some soil amendments which contain chitin and inorganic fertilizers that release ammoniacal nitrogen into soil suppress nematode populations directly and enhance the selective growth of microbial antagonists of nematodes. In general, nutrients can directly or indirectly predispose plants to pathogen attack. They can reduce or increase disease severity, affect the environment to attract or deter pathogens and also induce resistance or tolerance in the host plant (Zambolim et al., 2001; Agrios, 2005). There are still few studies on the influence of mineral nutrition on diseases caused by nematodes and some of the existing studies do not elucidate the mechanisms by which the nutrients reduce the phytoparasite population (Simone et al., 2013). Therefore, the objective of the present work was to examine the effect of plant mineral nutrition in comparison with oxamyl on root-knot nematode, $M$. incognita infecting tomato plant cv. Castle Rock under greenhouse conditions.

\section{Materials And Methods}

\section{Preparation of Nematodes Incula:}

Second stage juveniles (J2) of Meloidogyne incognita (Kofoid \& White) Chitwood were obtained from a pure culture of $M$. incognita that was initiated by single eggmass and propagated on coleus plants, Coleus blumei in the greenhouse of Nematology Research Unit, Agricultural Zoology Department, Faculty of Agriculture, Mansoura University, Egypt, where this work was carried-out. $M$. incognita second stage juveniles (j2) inocula prepared by extracting them from soil of infected coleus plants through sieving modified Baermann technique (Goodey,1957), and determined according to the design of the experiment in this investigation.

\section{Nematode Management Test:}

In order to study the effect of seven plant mineral nutrients i.e. calcium sulphate, zinc sulphate, magnesium sulphate, iron sulphate, potassium sulphate N.P.K(20:20:20) and urea separately in comparison with oxamyl on root-knot nematode infecting tomato plant cv. Castle Rock (Solanum lycopersicum L)under greenhouse conditions $\left(19 \pm 3^{\circ} \mathrm{C}\right)$, forty plastic pots (10 cm-diam.) containing one $\mathrm{kg}$ sterilized steam clay loamy soil $(1: 1, \mathrm{v}: \mathrm{v})$ with one tomato seedlings 30 day-old each were used in this study. One week after tomato seedlings transplanting, $1000 \mathrm{M}$. incognita juveniles were introduced to thirty six seedlings each and left four seedlings (pots) without nematode to serve as check.. One week later from nematode inoculation, the tested materials were separately added to four seedlings each and mixed with soil, while four seedlings (pots) with nematode only were left without any treatment. Each treatment was replicated four times. Treatments were as follows: 
1. $\mathrm{N}+$ calcium sulphate $(5 \mathrm{~g} / \mathrm{pot})$,

2. $\mathrm{N}+$ iron sulphate $(5 \mathrm{~g} / \mathrm{pot})$,

$3 . \mathrm{N}+$ magnesium sulphate $(5 \mathrm{~g} / \mathrm{pot})$,

4.N+ N.P.K (20:20:20) (5g / pot),

$5 . \mathrm{N}+$ potassium sulphate $(5 \mathrm{~g} / \mathrm{pot})$,

$6 . \mathrm{N}+$ urea $(5 \mathrm{~g} / \mathrm{pot})$,

$7 . \mathrm{N}+$ zinc sulphate $(5 \mathrm{~g} /$ pot $)$,

$8 . \mathrm{N}+$ oxamyl $(0.3 \mathrm{ml} / \mathrm{pot})$,

9. $\mathrm{N}$ alone and

10. Plant free of $\mathrm{N}$ and any treatment.

Plastic pots were then arranged in a randomized complete block design on a bench of greenhouse at $19 \pm 3^{\circ} \mathrm{C}$ and irrigated with tap water as needed. Plants were harvested after 45 days from nematode inoculation, and plant growth criteria i.e. shoot and root lengths and fresh weights, as well as shoot dry weights were determined and recorded. Number of $M$. incognita $\mathrm{J}_{2}$ in $250 \mathrm{~g}$. soil/pot were extracted by sieving and modified Baermann- technique (Goodey, 1957), then calculated for each pot, counted by Hawksely counting slide under $\times 10$ magnification and recorded. Infected roots of each plant/treatment were washed with tap water, fixed in $4 \%$ formalin for $24 \mathrm{hrs}$ and stained in 0.01 lactic acid-fuchsin (Byrd et al., 1983) and then examined for the number of galls, developmental stages, females and egg-masses. The root gall index (RGI) and egg mass index (EI) were estimated according to the scale given by Taylor and Sasser (1978) as follows: $0=$ no galls or egg-masses, $1=1-2$ galls or egg-masses, $2=3-10$ galls or egg-masses, $3=11-30$ galls or egg-masses, $4=31-100$ galls or egg-masses and $5=$ more than 100 galls or egg-masses. Statistically, the obtained data were subjected to analysis of variance (ANOVA) (Gomez and Gomez, 1984) followed by Duncan's multiple ranges to compare means (Duncan, 1955).

\section{Results and Discussion}

Data in Table (1) reveal the influence of seven plant mineral nutrients i.e. calcium sulphate, zinc sulphate, magnesium sulphate, iron sulphate, potassium sulphate N.P.K(20:20:20) and urea separately in comparison with oxamyl on rootknot nematode infecting tomato plant cv. Castle e Rock under greenhouse conditions. In general all tested materials significantly ameliorated tomato plant growth parameters to great extent. Among the tested plant mineral nutrients, calcium sulphate showed the maximum values in improving total plant fresh weight $(65.0 \%)$, plant length $(80.2 \%)$, shoot dry weight $(97.2 \%)$ and number of leaves per plant $(24.2 \%)$, followed by N:P:K (20:20:20) with values of $57.3,61.7,69.4$ and $24.2 \%$ for the same plant growth parameters, respectively, whereas, the zinc sulphate gave the minimum values for the same plant growth criteria that averaged $23.3,27.9,16.7$ and $8.1 \%$ respectively comparing to nematode alone. Moreover, 
Table (1): Impact of seven mineral nutrients on tomato plant or. Castle Rook in comparison with oxamyl under the stress of Meloridogyne incognita infection in the greenhouse $\left(19 \pm 3^{\circ} \mathrm{C}\right)$.

\begin{tabular}{|c|c|c|c|c|c|c|c|c|c|c|c|c|}
\hline \multirow{3}{*}{ Treatments } & \multicolumn{12}{|c|}{ "Plant growth response } \\
\hline & \multicolumn{2}{|c|}{ Length (cm) } & \multirow{2}{*}{ 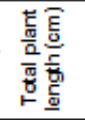 } & \multirow{2}{*}{$\begin{array}{l}\frac{8}{8} \\
\dot{8} \\
\frac{f}{8}\end{array}$} & \multirow{2}{*}{ 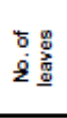 } & \multirow{2}{*}{ 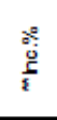 } & \multicolumn{2}{|c|}{ Fre shweight (g) } & \multirow{2}{*}{ 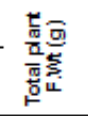 } & \multirow{2}{*}{$\frac{d}{g}$} & \multirow{2}{*}{$\begin{array}{l}\text { 둠 } \frac{0}{5} \\
\frac{8}{6} \\
\frac{5}{\omega}\end{array}$} & \multirow{2}{*}{$\frac{g}{8}$} \\
\hline & shoot & root & & & & & shoot & root & & & & \\
\hline Calcium sulphate & $28.5 a b$ & $11.5 \mathrm{a}$ & $40.0 \mathrm{~b}$ & 80.2 & $7.7 b$ & 24.2 & $13.6 \mathrm{~b}$ & $3.4 \mathrm{~b}$ & $17.0 \mathrm{~b}$ & 65.0 & $7.1 \mathrm{~b}$ & 97.2 \\
\hline Iron s ulphate & $21.0 \mathrm{c}$ & $9.0 \mathrm{~b}$ & $30.0 \propto$ & 35.1 & $7.0 \mathrm{~d}$ & 12.9 & $10.6 \mathrm{~d}$ & $3.8 \mathrm{~b}$ & $14.4 \mathrm{~d}$ & 39.8 & $4.6 \mathrm{e}$ & 27.8 \\
\hline Magnes ium Sulphate & $24.5 \mathrm{bc}$ & $8.8 \mathrm{~b}$ & $33.3 \mathrm{c}$ & 50.0 & $7.0 \mathrm{~d}$ & 12.9 & $9.3 \mathrm{e}$ & $5.9 \mathrm{a}$ & 15.2 od & 47.6 & $4.3 \mathrm{ef}$ & 19.4 \\
\hline N.P.K $20: 20: 20$ & $27.5 b$ & $8.4 \mathrm{~b}$ & $35.9 \mathrm{bc}$ & 61.7 & $7.7 \mathrm{~b}$ & 24.2 & 12.4 od & $3.8 \mathrm{~b}$ & $16.2 \mathrm{~b}$ & 57.3 & $6.1 \mathrm{c}$ & 69.4 \\
\hline Potas sium Sulphate & $26.0 \mathrm{~b}$ & $8.2 \propto$ & $34.2 \mathrm{bc}$ & 54.1 & $7.0 \mathrm{~d}$ & 12.9 & $10.3 d$ & $2.7 \mathrm{~d}$ & $13.0 \mathrm{e}$ & 26.2 & $5.9 \propto$ & 63.9 \\
\hline Urea & $25.7 \mathrm{~b}$ & $8.5 \mathrm{~b}$ & 34.2 bc & 54.1 & $7.5 \mathrm{c}$ & 21.0 & $12.6 \mathrm{c}$ & $3.1 \mathrm{c}$ & $15.7 \mathrm{c}$ & 52.4 & 4.5 ef & 25.0 \\
\hline Znc Sulphate & $20.0 \mathrm{c}$ & $8.4 b$ & $28.4 \mathrm{~d}$ & 27.9 & $6.7 \mathrm{e}$ & 8.1 & $9.3 \mathrm{e}$ & $3.4 \mathrm{bc}$ & $12.7 \mathrm{ef}$ & 23.3 & $4.2 \mathrm{ef}$ & 16.7 \\
\hline Oxamyl & $32.5 \mathrm{a}$ & $8.7 b$ & $412 \mathrm{a}$ & 85.6 & $8.2 \mathrm{a}$ & 32.3 & $16.3 \mathrm{a}$ & 3.3 bc & $19.6 \mathrm{a}$ & 90.3 & $8.0 \mathrm{a}$ & 122.2 \\
\hline Nalone & $16.7 \mathrm{~d}$ & $5.5 \mathrm{~d}$ & $22.2 \mathrm{e}$ & - & $6.2 \mathrm{~g}$ & - & $7.9 \mathrm{~g}$ & $2.4 \mathrm{e}$ & $10.3 \mathrm{~g}$ & - & $3.6 \mathrm{fg}$ & - \\
\hline Plant free of any treatment & $15.7 \propto$ & $7.2 \mathrm{c}$ & $22.9 \mathrm{e}$ & 3.2 & $6.4 \mathrm{f}$ & 3.2 & $8.0 \mathrm{f}$ & $3.0 \mathrm{c}$ & $11.0 \mathrm{f}$ & 6.8 & $3.9 \mathrm{f}$ & 8.3 \\
\hline
\end{tabular}

$N=1000$ eggs of $M$. Incogn tita

Each value is the mean of four replicates

- increase $\%=\frac{\text { Treatment }-\mathrm{N} \text { alone (Untreated) }}{\mathrm{N} \text { abne (Untreated) }} \times 100$ 
the soil fertilizered with urea showed moderately values of ameliorating plant parameters that averaged 52.4, 34.2, 25.0 and $21.0 \%$ for total plant fresh weight, plant length, shoot dry weight and number of leaves/plant respectively. However, oxamyl as a systemic nematicide at the recommended dose ranked first with increase values of plant length (85.6\%), total plant fresh weight (90.3), shoot dry weight (122.2)and number of leaves/ plant (32.3\%), as compared with nematode alone. Meanwhile, plant free of nematode and untreated with any tested materials showed reasonable percentage increase values that averaged 3.2, 3.2, 6.8 and $8.3 \%$ for plant length, number of leaves, total plant fresh weight and shoot dry weight, respectively (Table 1).

Data presented in Table (2) show nematode population densities in soil and root; and number of galls and egg-masses on tomato plant infected with $M$. incognita as affected by the tested seven mineral nutrients in comparison with oxamyl under greenhouse conditions $\left(19 \pm 3^{\circ} \mathrm{C}\right)$. It is evident that nematode criteria were also significantly influenced by all tested treatments comparing to nematode alone.

Plant receiving calcium sulphate accomplished the highest reduction percentage in nematode population density that averaged $92.3 \%$, followed by that of urea application with value of $85.5 \%$. The relative lowest reduction percentage of this nematode criterion was resulted by treatment of zinc sulphate with value of 58.5 $\%$ as compared with nematode alone, (Table 2). Also, rates of nematode build-up under the stress of seven mineral nutrients and oxamyl were adversely affected. Such rates ranged between 0.1 to 1.8 vs 4.2 for nematode alone. Namely, calcium sulphate treatment had reasonable lower value of reproduction, (0.3) while, that of zinc sulphate had the highest (1.8), whereas oxamyl recorded a lowest rate (0.11), respectively, as compared with nematode alone.

Concerning root galling, significant reduction in number of galls on tomato roots were achieved by all tested treatments, comparing to nematode alone since their indices ranged from 1.0 to 2.6 vs 3.0 for the tested materials and oxamyl vs the check (Table 2).

Among the tested seven mineral nutrients, calcium sulphate treatment significantly diminished final nematode population and number of galls on tomato roots with reduction percentage values of 92.3 and $76.5 \%$, followed by that of urea (85.5 \&72.9\%) comparing to the check, respectively. Similar trend was noticed in reduction of egg-mass numbers with values of 90.9 and $88.2 \%$ for calcium sulphate and urea treatments, since their indices ranged from 1.0 to 2.2 vs 3.0 respectively comparing to the check. It is worthy to note that zinc sulphate achieved the relative lowest reduction of final nematode population (58.8\%) whereas, the lowest gall and eggmass reduction percentages were evident when tomato plant received magnesium sulphate, since their values averaged 41.2 and $60.9 \%$ accompanied by gall and eggmass indices of 2.6 and 2.2, vs 3.0 for nematode alone, respectively. 
Table (2): Impact of seven mineral nutients in comparison with oxamyl on Meloidogyne incognita infecting on tomato plant of Castle Rook under greenhouse conditions $\left(19+3^{\circ} \mathrm{C}\right)$.

\begin{tabular}{|c|c|c|c|c|c|c|c|c|c|c|c|c|}
\hline \multirow[t]{2}{*}{ Tre atments } & \multirow{2}{*}{$\frac{3}{\sqrt[3]{8}}$} & \multicolumn{2}{|c|}{$\begin{array}{c}* \text { Nematode } \\
\text { population in } \\
\text { Root }\end{array}$} & \multirow{2}{*}{ 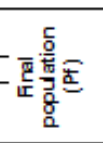 } & \multirow{2}{*}{ 崖 } & \multirow{2}{*}{$\frac{2}{g}$} & \multirow{2}{*}{ 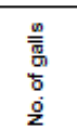 } & \multirow{2}{*}{$\bar{Q}$} & \multirow{2}{*}{$\frac{a}{2}$} & \multirow{2}{*}{ 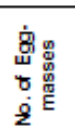 } & \multirow[t]{2}{*}{$\overline{\boldsymbol{w}}$} & \multirow{2}{*}{$\frac{2}{g}$} \\
\hline & & Females & $\begin{array}{c}\text { Dev. } \\
\text { stages }\end{array}$ & & & & & & & & & \\
\hline Calcium sulphate & $310 \mathrm{~h}$ & $14.3 \mathrm{a}$ & $1.33 d$ & $325.6 \mathrm{i}$ & 0.3 & 92.3 & $4.0 \mathrm{f}$ & 2.0 & 76.5 & $1.0 \mathrm{e}$ & 1.0 & 90.9 \\
\hline Iron sulphate & $1080 \mathrm{~d}$ & $14.3 \mathrm{a}$ & $2.3 \mathrm{~b}$ & $1096.6 \mathrm{~d}$ & 1.1 & 74.0 & $6.3 \mathrm{~d}$ & 2.6 & 62.9 & $1.3 \mathrm{~d}$ & 1.1 & 88.2 \\
\hline Magnesium Sulphate & $1440 \mathrm{c}$ & $14.3 \mathrm{a}$ & $2.3 \mathrm{~b}$ & $1456.6 \mathrm{c}$ & 1.5 & 85.5 & $10.0 \mathrm{~b}$ & 2.6 & 41.2 & $4.3 \mathrm{~b}$ & 2.2 & 80.9 \\
\hline N.P.K $20: 20: 20$ & $690 \mathrm{f}$ & $10.6 \mathrm{~d}$ & $1.6 \mathrm{c}$ & $7022 \mathrm{f}$ & 0.7 & 83.4 & $4.0 \mathrm{f}$ & 2.0 & 76.5 & $1.3 d$ & 1.1 & 88.2 \\
\hline Potassium Sulphate & $800 \mathrm{e}$ & $12.0 \mathrm{~b}$ & $2.0 \mathrm{bc}$ & $814.0 \mathrm{e}$ & 0.8 & 80.7 & $4.0 \mathrm{f}$ & 2.0 & 76.5 & $1.3 d$ & 1.1 & 88.2 \\
\hline Urea & 600 & 10.1 & $2.0 \mathrm{bc}$ & $612.1 \mathrm{~g}$ & 0.6 & 85.5 & $4.6 \mathrm{e}$ & 2.3 & 72.9 & $1.3 d$ & 1.1 & 88.2 \\
\hline Zinc Sulphate & $1740 \mathrm{~b}$ & $11.6 \mathrm{c}$ & $1.6 \mathrm{c}$ & $1753.3 b$ & 1.8 & 58.5 & $7.0 \mathrm{c}$ & 2.4 & 58.8 & $2.0 \mathrm{c}$ & 1.2 & 81.8 \\
\hline Oxamyl & $472 \mathrm{~g}$ & $2.30 \mathrm{f}$ & $1.33 \mathrm{~d}$ & $475.6 \mathrm{~h}$ & 0.11 & 88.7 & $2.0 \mathrm{~g}$ & 1.0 & 88.2 & $0 \mathrm{f}$ & 0 & 100.0 \\
\hline Nalone & $4200 a$ & $9.6 \mathrm{e}$ & $11.0 \mathrm{a}$ & $4220.6 \mathrm{a}$ & 4.2 & - & $17 a$ & 3 & - & $11.0 \mathrm{a}$ & 3.0 & - \\
\hline
\end{tabular}


Moreover, oxamyl as a systemic nematicide ranked second to calcium sulphate in suppressing nematode parameters with values of $88.7 \%$ for nematode population density, and ranked first in diminishing galls and eggmasses numbers with reduction percentage values of 88.2 and $100.0 \%$, respectively, comparing to nematode alone.

Apparently, results of the present investigation indicated that nematode criteria and host growth parameters were both obviously affected by mineral nutrients. Applying such fertilizer can, partially, offset nematode-induced damage by stimulating plant development (Ferraz et al., 2010). The general rule is that, if a nutrient is essential to a plant species, it should be supplied in balanced proportion to other essential nutrients, since deficiency can aggravate disease, especially in short-cycle crops (Zambolim et al., 2001). Calcium is an essential element for the integrity of the plant cell's plasmatic membrane, and more specifically ion-transport selectivity (Epstein and Bloom, 2004). Like other nutrients, calcium must be present in sufficient quantity in the soil, since calcium-deficient plants are more susceptible to nematode attack (Hurchanik et al., 2003). The calcium content of plant tissues can affect the incidence of diseases in two ways: a) when calcium levels are low, there is an increase in the efflux of compounds of low molecular weight (sugars) from the cytoplast to the apoplast, and b) calcium polygalacturonates are required for the middle lamella to stabilize the cell wall. Calcium plays a critical role in cell division and development, in the structure of the cell wall and in the formation of the middle lamella (Huber, 1991). Many phytopathogenic agents reach the plant tissue by producing extracellular pectolytic enzymes, such as galacturonase, that degrade the middle lamella (McGuire and Kelman, 1986), and the enzyme activity is dramatically inhibited by the presence of calcium (Marschner, 1997). Application of calcium carbide (CaC2) was effective in reducing the number of galls, egg masses and juveniles of $M$. incognita in zucchini (Cucurbita pepo var. Melopepo), regardless of the concentration used, increasing crop yield (Mohamed and Youssef, 2009). However, the form in which calcium is most widely used consists of liming, which is directly link to soil $\mathrm{pH}$. Rocha et al. (2006) evaluated the effect of increasing doses of lime on the population of Heterodera glycines in soybean roots and found that the number of females dropped as lime doses were increased up to $3.039 \mathrm{t}$ ha-1. The present findings are in agreement with Simone de Melo et al., (2013) who concluded that increasing the supply of calcium boosted the resistance of the cells, lowering root infection by such nematode.

The present findings are in agreement with those reported by Shalaby (2012) in respect to $\mathrm{CaCl} 2$ and $\mathrm{Mnso} 4$ at the high levels for controlling $M$. incognita on tomatoes, respectively. Moreover, in certain cases an increase in nematode galls and eggmasses numbers against the levels tested in this study may be occurred that is due to a negative effects of heavy metals such as zinc sulphate on some of 
their antagonists as reported by Georgieval et al., (2002). In conclusion, proper and good nutritional status of plants could enhance and magnify their defense systems against such nematode pathogens. As a whole, it can be concluded from the obtained results that all tested materials used improved plant growth of tomatoes and suppressed nematode population and development with great degrees. However, more research is needed to be done under field conditions before final recommendations can be made.

\section{References}

Agrios, G. N. (2005). Plant Pathology. 5a ed. London: Elsevier Academic Press. P. 922.

Byrd, D.W.; T. Kirkpatrick and K. Barker (1983). An improved technique for clearing and staining plant tissues for detection nematodes. J. Nematol., 15 (3): 142-143.

Duncan, D.B. (1955). Multiple range and multiple, F-test. Biometrics, 11: 1-42.

Epstein, E. and Bloom, A. (2004). Mineral Nutrition of Plants. Sunderland: Sinauer Associates. P. 380.

Ferraz, S; Freitas, L.G.; Lopes, E.A. and Dias-Arieira, C.R. (2010). Manejo sustentável de fitonematoides. Viçosa: Editora UFV. P. 306.

Georgieval, S. S.; McGrath, S. P.; Hooper, D. J. and Chmbers, B. S. (2002). Nematode communities under stress of the long term effects of heavy metals in soil treated with sewage sluge. Applied soil Ecol., 20(1): 27-42.

Gomez, K. A. and Gomez, A.A. (1984). Statistical procedures for Agricultural Research. 2nd Ed., John Wiley \&Sons: Inc., New York.

Goodey, J.B. (1957). Laboratory methods for work with plant and soil nematodes. Tech. Bull. No. 2. Min. Agric. Fish Ed. London, 47 pp.

Huber, D.M. (1991). The use of fertilizers and organic amendments in the control of plant disease. In: Pimentel D, Hanson AA (ed) Handbook of pest management in agriculture. Flórida: CRC, pp. 357-394.

Hurchanik, D.; Schmitt, D.P.; Hue, N.V. and Sipes, B.S. (2003). Relationship of Meloidogyne konaensis population densities to nutritional status of coffee roots and leaves. Nematropica 33:55-64.

Marschner, H. (1997). Mineral nutrition of higher plants. London: Academic Press. P. 889.

McGuire, R.G.; Kelman, A. (1986). Calcium in potato tuber cell walls in relation to tissue maceration.

Rocha M.R.; Carvalho, I.; Corrêa, G.C.; Cattini, G.P. and Paolini, G. (2006). 
Efeito de doses crescentes de calcário sobre a população de Heterodera glycines em soja. Pesq. Agropec. Trop. 36:89-94.

Shalaby, M. M. Marwa (2012) Root-knot nematode Meloidogyne incognita management on tomato plants by various biological agents. Ph. D Thesis. Zool. Dept., Fac of Agric., Mansoura Univ., 195pp.

Simone, M. S.; Claudia, R. D.; Miria, R.; Tais, S. D.; Patricia, M. M. and Davi Antonio O. B. (2013). Mineral nutrition in the control of nematodes. African J. Agric. Res. 8(21): 2413-2420.

Taylor, A. L., and Sasser, J. N. (1978). Biology, identification and control of rootknot nematodes (Meloidogyne species). Raleigh, NC: North Carolina State University Graphics.

Zambolim, L.; Costa, H. and Vale, F.X.R. (2001). Efeito da nutrição mineral sobre doenças de plantas causadas por patógenos de solo. In: Zambolim L (ed) Manejo integrado fitossanidade: cultivo protegido, pivô central e plantio direto. Viçosa: Editora UFV. pp. 347-408. 


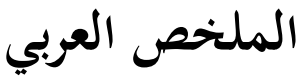

Meloidogyne تأثير التغذية المعدنية على الطماطم المصابة بنيماتودا تعقد الجذور incognita

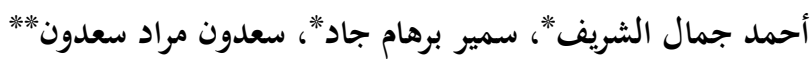

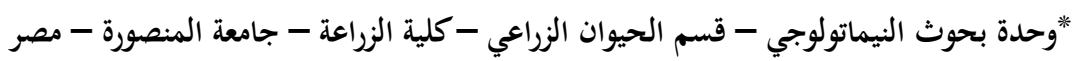

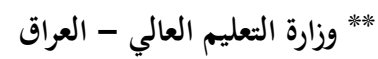

تعتبر الطماطم (Solanum lycopersicum) أحد الخضروات الأكثر أهمية في العالم. تسبب نيماتودا تعقد الجذور (Meloidogyne incognita) العديد من المشاكل في العاطي

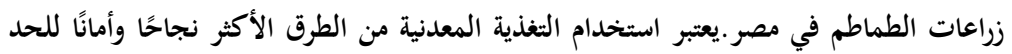

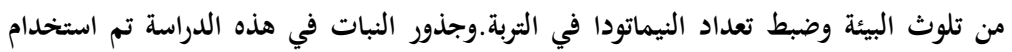

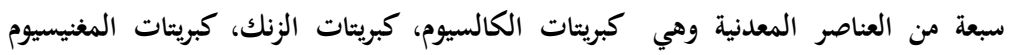

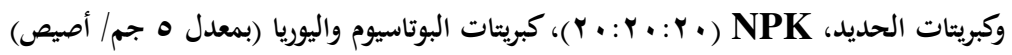

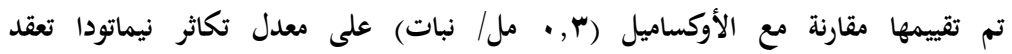

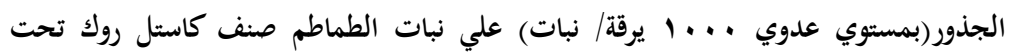

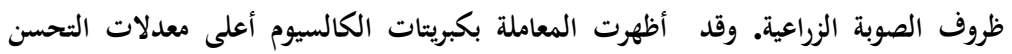

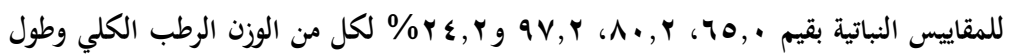

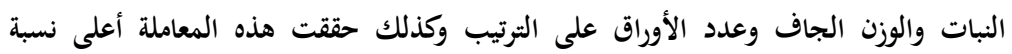

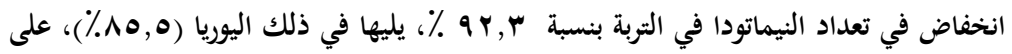

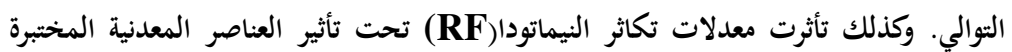

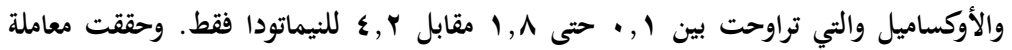

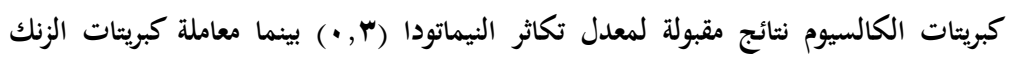

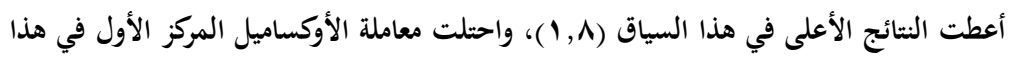

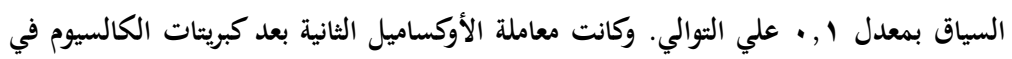

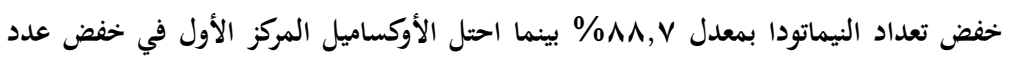

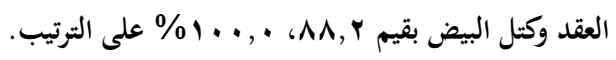

